\title{
Effect of Pre-Processing Steps, Nitrite and Irradiation Combination Preservation of a Ready-to-Eat Spinach Relish and Sorghum Porridge Meal
}

\author{
Renatus P. Shilangale ${ }^{1,2}$ \\ ${ }^{1}$ Central Veterinary Laboratory, Ministry of Agriculture Water and Forestry, Windhoek, Namibia; ${ }^{2}$ Department of Food Science, \\ Faculty of Natural and Agricultural Sciences, University of Pretoria, Pretoria, Republic of South Africa. \\ Email: rpshilangale@yahoo.com
}

Received December 30 ${ }^{\text {th }}, 2011$; revised April 6 ${ }^{\text {th }}, 2012$; accepted April $13^{\text {th }}, 2012$

\begin{abstract}
The effects of pre-processing steps (washing, blanching and cooking) and combination preservation of irradiation (10 $\mathrm{kGy})$ and nitrite $\left(0,50,100,150\right.$ and $\left.200 \mathrm{mg} \cdot \mathrm{kg}^{-1}\right)$ on the survival of Clostridium sporogenes spores in a ready-to-eat (RTE) spinach relish and sorghum porridge meal were investigated. Chlorine wash $\left(250 \mathrm{mg} \cdot \mathrm{l}^{-1}\right)$ reduced the $C$. sporogenes counts in spinach by 1.6 log cycles. Blanching following the chlorine wash caused no significant decrease in the spore counts in spinach. On the other hand, cooking significantly reduced the counts in the porridge by about 1.7 log cycles. In both components of the meal, there was a significant decrease in the Clostridia counts with increased sodium nitrite levels. However, the counts increased in the sorghum porridge component after $12 \mathrm{~d}$ of storage at $10^{\circ} \mathrm{C}$. Cooking alone significantly reduced the final nitrite levels in both components of the meal. In both components of the meal, nitrite in combination with irradiation reduced the $C$. sporogenes counts to less than $10 \mathrm{cfu} / \mathrm{g}$. A safe RTE spinach relish and sorghum porridge meal could be expected when a pre-processing, followed by a combination treatment of at least $50 \mathrm{mg} \cdot \mathrm{kg}^{-1}$ sodium nitrite and a target dose of $10 \mathrm{kGy}$ is applied.
\end{abstract}

Keywords: Ready-to-Eat (RTE) Meal; Nitrite; Irradiation

\section{Introduction}

In South Africa, most of the African people in formal and informal urban areas depend on commercially produced food products. It has also been shown that significant numbers of these people prefer traditional meals. However, traditional foods are not commercially produced, have a short shelf life and are laborious to prepare.

Few studies have been done on the preservation of RTE foods such as spinach morôgo and sorghum porridge. However, the survival and growth of pathogens in RTE meals is possible. Previous study in RTE spinach and sorghum porridge meal produced by a combination of Modified Atmosphere Packaging (84.5\% $\mathrm{N}_{2}+15.5 \% \mathrm{CO}_{2}$ ) with irradiation (10 kGy) found the possible growth of Clostridium botulinum if the meal is temperature abused [1].

From the microbiological point of view, food irradiation alone has two potential advantages, first it reduces the number of pathogens and so increases food safety, and secondly it extends the shelf life of the product by reducing the number of spoilage organisms [2]. However, one of the major concerns about food irradiation is that insufficient doses of radiation might serve as a mutagenic catalyst that could create radiation-resistant strains, in the same way that certain strains of microbes have developed resistance to antibiotics [3]. On the other hand, the formation of benzine (and its delivetives) and alkylcyclobutanones (ACBs) has become a food safety concern because of the potential of ACBs to induce DNA damage which have been observed under experimental conditions [4]. So far, regulatory and health organizations recommend that food irradiation below $10 \mathrm{kGy}$ as safe level [4]. However, irradiation alone at $10 \mathrm{kGy}$ dosage does not render food free from pathogenic bacteria.

Hence, there is a need to try other methods or a combination of methods to ensure the safety of RTE meals and avoid the use of higher irradiation dosage. A combination preservation methods such as sodium nitrite in combination with irradiation could be considered. Sodium nitrite has been found to be effective in preventing outgrowth of C. botulinum in temperature abused cured meat products. A considerable amount of research has been done relating to the use of nitrites in perishable cured meat such as bacon, sausages, vieners and canned hams [5] but very 
little research has been done on ready-to-eat (RTE) meals.

The objective of this study was to investigate the effects of the pre-processing steps and nitrite-irradiation combination processing on the safety of a RTE sorghum porridge and spinach morôgo meal.

\section{Materials and Methods}

\subsection{Effects of Pre-Processing Steps on $C$. sporogenes Spores}

Pre-processing treatments were followed in order to reduce the spore counts in the raw materials prior to further processing. Figure 1 gives the summary of the process description.

\subsection{Preparation of a RTE Sorghum Porridge and Spinach Relish}

Sorghum porridge and spinach based relish meals were prepared following the method adapted from Duodu et al. (Figure 2) [6]. Samples of the product were taken immediately before and after irradiation and the Clostridia

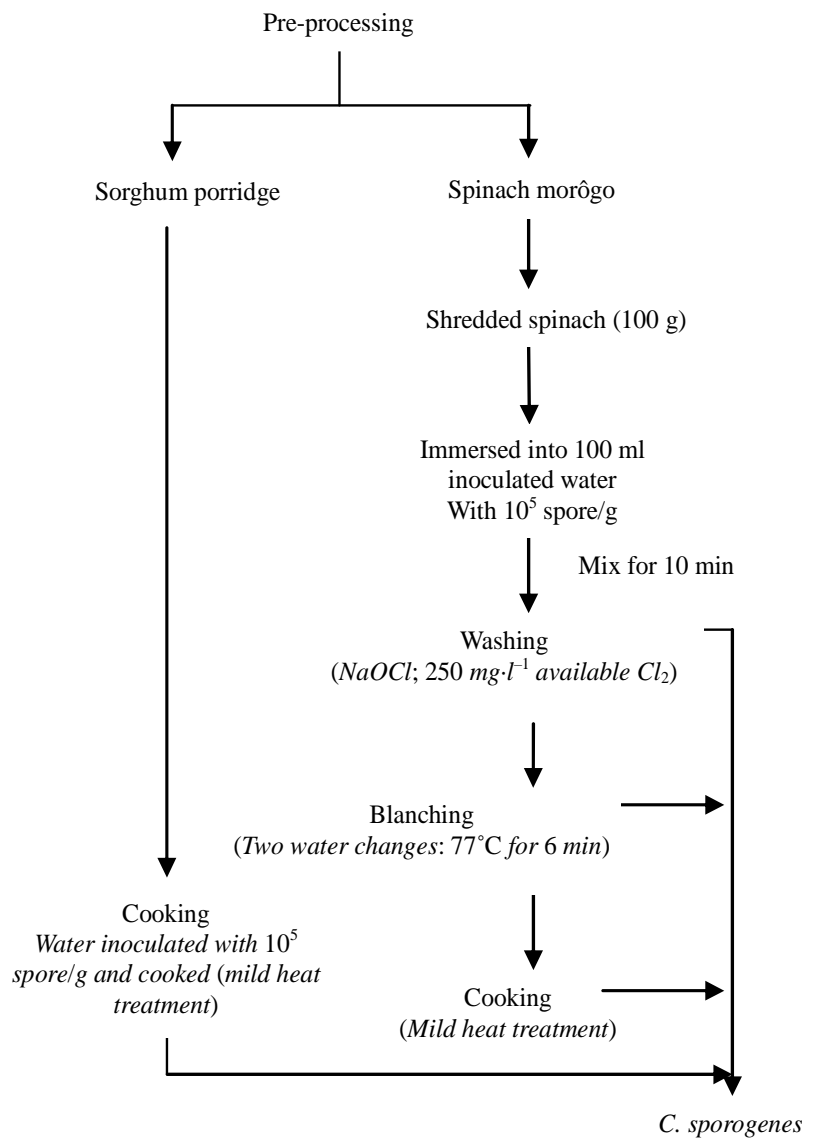

Figure 1. Pre-processing steps of spinach morôgo and sorghum porridge meal.

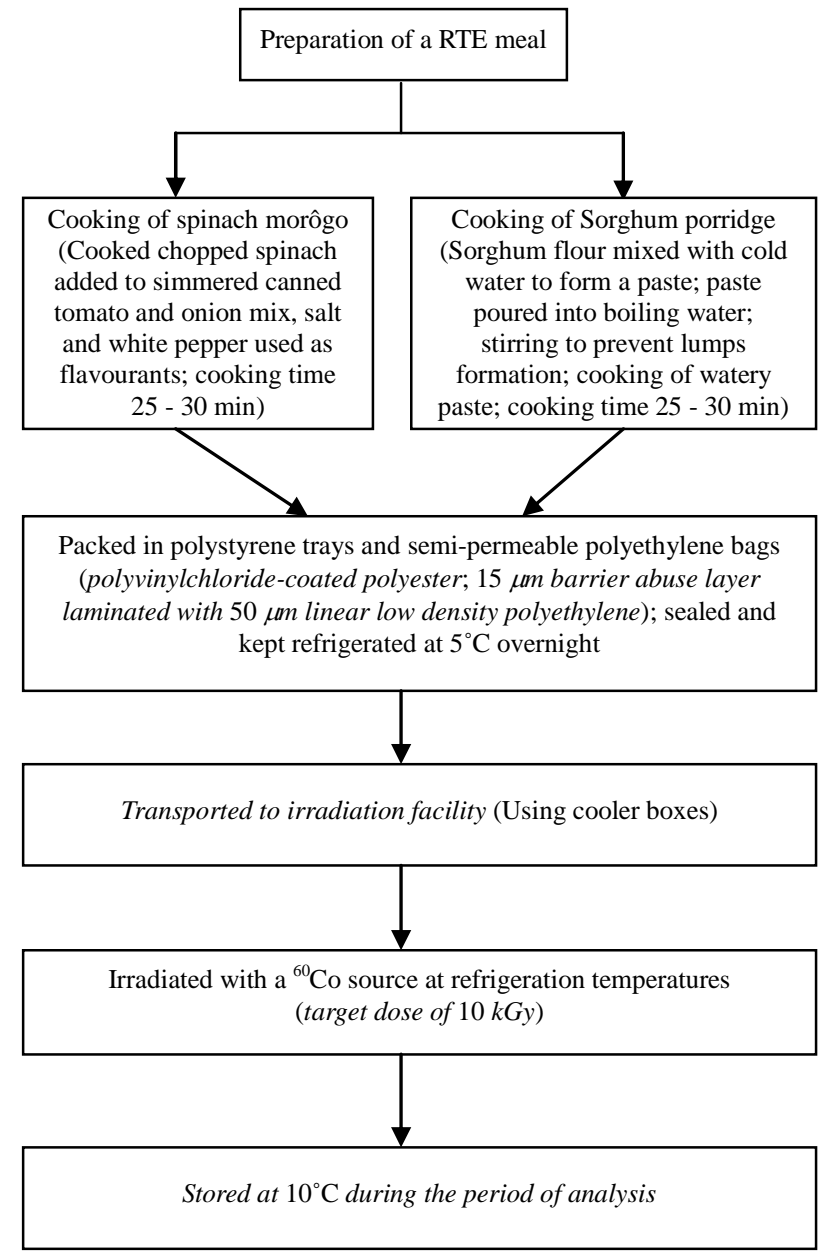

Figure 2. Flow diagram of preparation and processing of RTE spinach morôgo and sorghum porridge meal.

counts were performed on day 1, 6 and 12 after irradiation. The time intervals used for Clostridia count were chosen based on a previous study by Obilana [1]. Storage temperature of $10^{\circ} \mathrm{C}$ was chosen in order to determine the safety of the RTE food in case of temperature abuse during storage. Although samples were irradiated at a target dose of $10 \mathrm{kGy}$, samples received irradiation doses of 13.8, 10.4, 10.0 and $12.3 \mathrm{kGy}$ at a dose rate of $1.4 \mathrm{kGy} / \mathrm{h}$ for the first to the fourth replicates respectively.

\subsection{Determination of Residual Sodium Nitrite}

Residual sodium nitrite levels in RTE sorghum porridge and spinach relish were determined using the Association of Analytical Communities (AOAC) Official Method of Analysis [7].

\subsection{Microbiological Analysis}

\subsubsection{Sampling and Preparation of Dilutions}

Tenfold serial dilutions of the samples were made by 
aseptically transferring $20 \mathrm{~g}$ of sample into a sterile stomacher bag containing $180 \mathrm{ml}$ of sterile $0.1 \%$ peptone water. Samples were homogenised for 0.5 to $1 \mathrm{~min}$ using a Stomacher 400 laboratory blender (Seward Laboratory UAC House, Britain). Further dilutions $\left(10^{-2}, 10^{-3}, 10^{-4}\right.$, $10^{-5}$ and $10^{-6}$ ) were made by transferring $1 \mathrm{ml}$ of successive serial dilutions into McCartney bottles containing 9 $\mathrm{ml}$ of sterile peptone water.

\subsubsection{Enumeration of $C$. sporogenes}

C. sporogenes spore suspension (isolates $\mathrm{Cl}_{3}, \mathrm{Cl}_{5}$ and $\mathrm{Cl}_{10}$ ) was enumerated as described by Anellis et al. [8]. Cells were not heat shocked because the preparation of samples involved a cooking process whereby the temperature and time used were enough to activate spore germination. Peptone P (Merck, Wadeville, South Africa) was used to prepare Tryptic Yeast Thioglycolate agar instead of Thiotone (BBL).

\subsection{Statistic Analysis}

The analysis of variance (ANOVA) was carried out using a Statistica Version 5.0 from the Microsoft Corporation. The least significant difference test (LSD-test) was used to determine whether a difference existed between means of treatments. All comparisons were done at a level of $5 \%$ significance.

\section{Results}

The effects of pre-processing steps on the survival of inoculated C. sporogenes spores in the spinach and sorghum porridge components are shown in Table 1. The analysis of variance revealed that there was a significant $(p<0.05)$ decrease of $1.6 \log _{10} \mathrm{cfu} / \mathrm{g}$ in the spores survived in spinach washed with $250 \mathrm{mg} \cdot \mathrm{l}^{-1} \mathrm{NaOCl}$. No significant decrease of spores was observed after subsequent blanching in two water changes (at $77^{\circ} \mathrm{C}$ for $7 \mathrm{~min}$ ).

Table 1. Effect of pre-processing of spinach and sorghum porridge on the survial of $C$. sporogenes $\left(\log _{10} \mathrm{cfu} / \mathrm{g}\right)$.

\begin{tabular}{lcc}
\hline \multicolumn{1}{c}{ Treatment } & Spinach $^{1}$ & Porridge $^{1}$ \\
\hline Initial spore inoculation & $5.0^{\mathrm{c}}$ & $4.7^{\mathrm{b}}$ \\
& $( \pm 0 .)^{2}$ & $( \pm 0.2)$ \\
Washing (Chlorinated $\left.\mathrm{H}_{2} \mathrm{O}\right)$ & $3.4^{\mathrm{a}}$ & \\
& $( \pm 0.3)$ & $\mathrm{N} / \mathrm{A}$ \\
Blanching & $3.1^{\mathrm{a}}$ & \\
& $( \pm 0.2)$ & $\mathrm{N} / \mathrm{A}$ \\
Cooking & $4.0^{\mathrm{b}}$ & $3.0^{\mathrm{a}}$ \\
& $( \pm 0.4)$ & $( \pm 0.2)$ \\
\hline
\end{tabular}

${ }^{1}$ Mean values in the same column with different letters differ significantly ( $\mathrm{P}$ $<0.05)$ from each other; ${ }^{2}$ Standard deviations are given in brackets. N/A: not applicable.
The Clostridia counts after cooking were significantly higher than those after blanching. With sorghum porridge, a significant $(\mathrm{p}<0.05)$ decrease of $1.7 \log _{10} \mathrm{cfu} / \mathrm{g}$ in the number of $C$. sporogenes spores was observed after cooking.

Table 2 shows the effect of different sodium nitrite levels on the survival of the inoculated $C$. sporogenes spores and their subsequent growth in the spinach component of the meal stored at $10^{\circ} \mathrm{C}$ for $12 \mathrm{~d}$ period. Statistical analysis showed that there was a significant decrease $(\mathrm{p}<0.05)$ in the $C$. sporogenes counts with increased sodium nitrite concentration. However, there was no significant $(\mathrm{p}<0.05)$ change in the spore counts over time.

Table 3 shows the effect of different sodium nitrite levels on the survival of the inoculated $C$. sporogenes

Table 2. Effect of different nitrite levels on the survival of the inoculated $C$. sporogenes $\left(\log _{10} \mathrm{cfu} / \mathrm{g}\right)$ in the spinach relish component of the meal stored at $10^{\circ} \mathrm{C}$ for 12 days.

\begin{tabular}{ccccccc}
\hline \multirow{2}{*}{ Time (days) } & \multicolumn{6}{c}{ Added nitrite levels $\left(\mathrm{mg} \cdot \mathrm{kg}^{-1}\right)$} \\
\cline { 2 - 7 } & 0 & 50 & 100 & 150 & 200 & Time effect $^{1}$ \\
\hline \multirow{2}{*}{1} & 4.1 & 4.1 & 4.1 & 2.3 & 2.9 & $3.9^{\mathrm{a}}$ \\
& $( \pm 0.3)^{3}$ & $( \pm 0.1)$ & $( \pm 0.2)$ & $( \pm 0.1)$ & $( \pm 0.1)$ & $( \pm 0.5)$ \\
6 & 5.0 & 3.7 & 3.3 & 3.2 & 3.3 & $3.7^{\mathrm{a}}$ \\
& $( \pm 0.4)$ & $( \pm 0.3)$ & $( \pm 0.1)$ & $( \pm 0.1)$ & $( \pm 0.1)$ & $( \pm 0.7)$ \\
12 & 4.5 & 3.5 & 3.5 & 3.1 & 2.8 & $3.5^{\mathrm{a}}$ \\
& $( \pm 0.3)$ & $( \pm 0.2)$ & $( \pm 0.3)$ & $( \pm 0.8)$ & $( \pm 0.5)$ & $( \pm 0.7)$ \\
Treatment effect $^{2}$ & $4.5^{\mathrm{d}}$ & $3.7^{\mathrm{c}}$ & $3.6^{\mathrm{bc}}$ & $3.4^{\mathrm{b}}$ & $3.0^{\mathrm{a}}$ & \\
& $( \pm 0.5)$ & $( \pm 0.3)$ & $( \pm 0.4)$ & $( \pm 0.5)$ & $( \pm 0.3)$ & \\
\hline
\end{tabular}

${ }^{1}$ Mean values in the same column with different letters differ significantly (p $<0.05$ ) from each other; ${ }^{2}$ Mean values in the same row with different letters differ significantly from each other; ${ }^{3}$ Standard deviations are given in brackets.

Table 3. Effect of different nitrite levels on the survival of the inoculated $C$. sporogenes $\left(\log _{10} \mathrm{cfu} / \mathrm{g}\right)$ in the sorghum porridge component of the meal stored at $10^{\circ} \mathrm{C}$ for 12 days.

\begin{tabular}{ccccccc}
\hline \multirow{2}{*}{ Time (days) } & \multicolumn{6}{c}{ Added nitrite levels $\left(\mathrm{mg} \cdot \mathrm{kg}^{-1}\right)$} \\
\cline { 2 - 7 } & 0 & 50 & 100 & 150 & 200 & Time effect $^{1}$ \\
\hline \multirow{2}{*}{1} & 3.0 & 2.7 & 2.5 & 2.5 & 2.9 & $2.7^{\mathrm{a}}$ \\
& $( \pm 0.2)^{3}$ & $( \pm 0.2)$ & $( \pm 0.3)$ & $( \pm 0.2)$ & $( \pm 0.6)$ & $( \pm 0.4)$ \\
6 & 4.8 & 2.9 & 2.9 & 2.6 & 2.5 & $3.1^{\mathrm{a}}$ \\
& $( \pm 0.4)$ & $( \pm 0.2)$ & $( \pm 0.2)$ & $( \pm 0.4)$ & $( \pm 0.3)$ & $( \pm 0.9)$ \\
12 & 5.5 & 4.9 & 2.5 & 3.2 & 2.9 & $4.0^{\mathrm{b}}$ \\
& $( \pm 0.7)$ & $( \pm 0.4)$ & $( \pm 0.3)$ & $( \pm 0.4)$ & $( \pm 0.4)$ & $( \pm 1.1)$ \\
Treatment effect $^{2}$ & $4.4^{\mathrm{c}}$ & $3.5^{\mathrm{b}}$ & $3.0^{\mathrm{a}}$ & $2.8^{\mathrm{a}}$ & $2.8^{\mathrm{a}}$ & \\
& $( \pm 1.2)$ & $( \pm 1.1)$ & $( \pm 0.6)$ & $( \pm 0.4)$ & $( \pm 0.5)$ & \\
\hline
\end{tabular}

${ }^{1}$ Mean values in the same column with different letters differ significantly (p $<0.05$ ) from each other, ${ }^{2}$ Mean values in the same row with different letters differ significantly from each other; ${ }^{3}$ Standard deviations are given in brackets. 
spores and their subsequent growth in the sorghum porridge component of the meal stored at $10^{\circ} \mathrm{C}$ for a period of $12 \mathrm{~d}$. Overall, there was a significant decrease $(\mathrm{p}<$ 0.05 ) in clostridia count for samples treated with 0 and $50 \mathrm{mg} \cdot \mathrm{kg}^{-1}$ of sodium nitrite. The two samples also differed significantly from the other samples. However, there was no significant difference between the other three samples. The overall time effect showed that there was no significant increase $(p>0.05)$ in Clostridia count between day 1 and day 6, but there was a significant increase of a $1.0 \log$ cycle in Clostridia counts after $12 \mathrm{~d}$ of storage.

Results on the effect of cooking alone, and the effect of cooking and irradiation on the residual sodium nitrite level in the RTE spinach based relish and sorghum porridge meal are showed in Table 4. Cooking reduced the nitrite level significantly $(\mathrm{p}<0.05)$ in both the spinach relish and the sorghum porridge components. A decrease in nitrite levels of between $85 \%$ and $92 \%$ was observed after cooking spinach, while a decrease of between $62 \%$ and $75 \%$ was observed in sorghum porridge after cooking. The residual nitrite level after cooking and irradiation was 355\% - $510 \%$ higher than after cooking alone. In the case of the sorghum porridge, the residual nitrite level was virtually the same after cooking and after cooking and irradiation.

Nitrite in combination with irradiation reduced the $C$. sporogenes counts in both components of the meal to less than $10 \mathrm{cfu} / \mathrm{g}$ immediately after irradiation (results not shown). No significant increase $(\mathrm{p}<0.05)$ in Clostridia count was observed with time in the sorghum porridge. However, there was a significant increase $(p<0.05)$ of $4.15 \times 10^{2} \mathrm{cfu} / \mathrm{g}$ in the spinach relish component on day 6 for the sample treated with $0 \mathrm{mg} \cdot \mathrm{kg}^{-1}$ nitrite and 3.55 $\times 10^{2}$ and $5.05 \times 10^{2} \mathrm{cfu} / \mathrm{g}$ on day 12 for the samples treated with 150 and $200 \mathrm{mg} \cdot \mathrm{kg}^{-1}$ nitrite respectively.

Table 4. Effect of cooking alone, and in combination with irradiation (10 $\mathrm{kGy})$ on the residual nitrite levels $\left(\mathrm{mg} \cdot \mathrm{kg}^{-1}\right)$ in spinach relish and sorghum porridge.

\begin{tabular}{lcccc}
\hline \multirow{2}{*}{\multicolumn{1}{c}{ Treatments }} & \multicolumn{4}{c}{ Initial (added) nitrite concentration } \\
& 50 & 100 & 150 & 200 \\
\cline { 2 - 5 } & $7.6^{\mathrm{a}}$ & $\left.9 . \mathrm{kg}^{-1}\right)^{1}$ & $13.5^{\mathrm{a}}$ & $15.7^{\mathrm{a}}$ \\
\hline Spinach relish & $( \pm 1.1)^{2}$ & $( \pm 1.9)$ & $( \pm 1.7)$ & $( \pm 1.7)$ \\
After cooking & $40.1^{\mathrm{b}}$ & $59.1^{\mathrm{b}}$ & $67.3^{\mathrm{b}}$ & $71.2^{\mathrm{b}}$ \\
After cooking and irradiation & $( \pm 4.1)$ & $( \pm 23.0)$ & $( \pm 25.7)$ & $( \pm 27.7)$ \\
& $19.2^{\mathrm{a}}$ & $35.3^{\mathrm{a}}$ & $38.5^{\mathrm{a}}$ & $49.3^{\mathrm{a}}$ \\
Sorghum porridge & $( \pm 1.1)$ & $( \pm 1.9)$ & $( \pm 5.3)$ & $( \pm 8.1)$ \\
After cooking & $19.6^{\mathrm{a}}$ & $29.9^{\mathrm{a}}$ & $39.4^{\mathrm{a}}$ & $52.0^{\mathrm{a}}$ \\
After cooking and irradiation & $( \pm 1.1)$ & $( \pm 5.1)$ & $( \pm 9.6)$ & $( \pm 10.2)$ \\
\hline
\end{tabular}

${ }^{1}$ Mean values in the same column with different letters differ significantly (p $<0.05$ ) from each other; ${ }^{2}$ Standard deviations are given in brackets.

\section{Discussion}

An irradiation dose of $10 \mathrm{kGy}$ was chosen as a cut-off point in this study following a consumer sensory acceptability test of a RTE meal (results not shown). The results showed that the two components of the meal remained acceptable up to $10 \mathrm{kGy}$. The limiting factor for using higher doses was the porridge component losing its appearance, texture and taste with increased irradiation dose. Meanwhile, the irradiation dose of $10 \mathrm{kGy}$ used in this study is the maximum dose allowed in food according to the Codex standards [9].

Pre-processing (washing, blanching and cooking) steps were followed in order to reduce the initial spore counts of the spinach before further processing. The significant decrease in the number of spores surviving after washing spinach with $250 \mathrm{mg} \cdot \mathrm{l}^{-1} \mathrm{NaOCl}$ could be attributed to the sporicidal effect of the chlorine compound [10]. Contrary to what was expected, blanching in two water changes did not significantly reduce the number of $C$. sporogenes spores inoculated in spinach. However, the findings of the present study were similar to a different study by Obilana [1]. The possible reason for blanching being ineffective after chlorine wash was that $C$. sporogenes spores that survived the chlorine wash at the concentrations used were resistant to blanching at $77^{\circ} \mathrm{C}$ for $6 \mathrm{~min}$ [2].

The greater survival of spores observed after cooking spinach could be due to spore activation by heat during cooking. The spores are normally activated by heat treatment, which triggers their germination and outgrowth [11, 12]. Meanwhile, the lower survival of spores in sorghum porridge was probably due to the fact that porridge takes longer period to cool than spinach. Hence, there is a possibility that the vegetative cells that have germinated during cooking of the sorghum porridge were inactivated or were heat-injured due to the long exposure of vegetative cells to heat. This could have affected their viability and therefore prevent them from germinating. The heat treatment of spores at $85^{\circ} \mathrm{C}$ is thought to inactivate the germination system of non-proteolytic Clostridium spp. [13].

The findings on both components of the meal where the higher levels of added sodium nitrite resulted to lower $C$. sporogenes counts in both components of the meal were probably due to the ability of the nitrite to inhibit growth of Clostridium spp. The significant decrease in the counts with increased nitrite levels could probably be that more nitrite remained available for inhibition when used at higher concentration than lower concentration.

With regard to the spinach relish components of the meal, there was no significant increase of Clostridia counts with time. This could be due to the amount of 
nitrite and nitrate available in spinach naturally. Under certain conditions nitrate can be reduced to nitrite and thereby reduce Clostridia counts with time, or at least prevent their increase. This is due to the inhibitory effect of the nitrite. However, the increased inhibitory effect of nitrite when heated could be another possible reason for the lower counts observed in the spinach component [14]. It appears that the formation of these inhibitors is due to involvement of nitrite, iron and sulfhydryl groups [15]. Nitrite and iron are usually more available in spinach than in sorghum grain. The lower level of these substances in sorghum porridge could be the reason for the significant increase of the $C$. sporogenes counts in the sorghum porridge components of the meal after $12 \mathrm{~d}$ of storage at $10^{\circ} \mathrm{C}$, which was not observed in the spinach. On the other hand, porridge is more likely than the spinach relish to have developed pronounced internal anaerobiosis due to the cooking effect. This is because heat promotes the expulsion of air, and the thickness of the porridge would likely make it an ideal growth medium for anaerobic Clostridia.

The decreasing trend of nitrite concentration observed in the present study was similar to those of Abo Bakr et $a l$. who found a decrease of $40.9 \%$ nitrite in jew's mallow after cooking [16]. The differences in percentage decrease found in this study as compared to that of Abo Bakr et al. was probably due to the differences in the initial levels of nitrite in the two products and the cooking procedures. The decrease in final nitrite levels in the two meals components may be attributed to leaching during the cooking process because of the high solubility of nitrite. However, there is also a possibility that nitrite might have changed to another form and evaporated with water. Nitrite can be reduced to nitric oxide by using most reducing agents at room temperature, whereas conversion of nitrate to nitric oxide requires strong reducing agents such as iron and tin with high temperature [17]. The higher levels of nitrite observed in the sorghum porridge as compared to those in the spinach after cooking could be due to the transformation of nitrite into other forms and the formation of complexes with other inorganic substances during cooking. The levels of inorganic substances are more likely to be more in spinach than porridge.

The effect of irradiation after cooking on the residual nitrite level in the spinach component of the meal is similar to that observed by Mondy et al. [18]. The three found that an irradiation dose of $1.0 \mathrm{kGy}$ increased the nitrite-nitrogen concentration of potato tubers up to $300 \%$ as compared to the controls. During irradiation in the presence of oxygen, highly oxidising free radicals may be formed [19] and these may oxidise nitrogen from sources such as protein and nucleic acids leading to an increase in nitrate [6]. The same mechanisms could pos- sibly result in an increase in the nitrite levels in the spinach relish. The smaller increase in nitrite observed in the sorghum porridge could be due to lower nitrate levels in cereal grains than that found in vegetables. The amount of nitrate present can be considered as the index of the amount of nitrite which may be formed during processing [1].

The reduction of the $C$. sporogenes counts in the components of the meal to less than $10 \mathrm{cfu} / \mathrm{g}$ after irradiation could be due to the low initial spore counts after cooking; i.e. 4.1 and $3.0 \log _{10} \mathrm{cfu} / \mathrm{g}$ in spinach relish and sorghum porridge respectively. A different study has found that irradiation at 5 and $10 \mathrm{kGy}$ would reduce the number of viable bacteria in poultry viscera by 4 to 6 cycles respectively [20]. Thus, with the initial spore counts of about 4 $\log _{10} \mathrm{cfu} / \mathrm{g}$ before irradiation, one would expect less than $10 \mathrm{cfu} / \mathrm{g}$ of viable bacteria to remain after irradiation.

The other possible explanation for the low count after irradiation is that nitrite increases the germination rates of spores that survived heating [21] which potentiate the direct killing effect of the vegetative cells. Bacterial spores are more resistant to the lethal action of ionising radiation than their corresponding vegetative cells by a factor of about 5 to 15 [19]. Therefore, if there is nitrite induced germination during processing, more cells would be inactivated during irradiation at $10 \mathrm{kGy}$. On the other hand, the formation of sugar acids and keto sugars increases when starch is irradiated in the presence of oxygen. The formation of acids leads to a decrease in the $\mathrm{pH}$ of irradiated sugar solutions, which can prevent the outgrowth of the bacteria spores [22]. This could be another reason for the lower counts $(<10 \mathrm{cfu} / \mathrm{g})$ in the sorghum porridge meal in all treatments.

\section{Conclusion}

The nitrite in combination with irradiation reduced the counts of $C$. sporogenes to undetectable levels for at least $6 \mathrm{~d}$ in both components of the meal regardless of the nitrite levels. This finding suggests that, if the meal had undergone pre-processing, lower initial levels of spores would be expected and the combination treatment would reduce the counts at least $4 \log$ cycles. Therefore, a safe ready-to-eat meal would possibly be expected when a pre-processing followed by a combination treatment of at least $50 \mathrm{mg} \cdot \mathrm{kg}^{-1}$ of nitrite and a target dose of $10 \mathrm{kGy}$ of irradiation had been applied. However, this would depend on the absence of any further contamination of the meal.

\section{REFERENCES}

[1] A. O. Obilana, "Modified Atmosphere Packaging and Irradiation Preservation of Sorghum Porridge and Spin- 
ach Relish Meal,” M.Sc. Dissertation, University of Pretoria, Pretoria, 1998.

[2] D. J. Olson, "Irradiation of Food: A Publication of the Institute of Food Techologist's Expert Panel on Food Safety and Nutrition," Food Technology, Vol. 52, No. 1, 1998, pp. 56-62.

[3] J. E. Prejean, “Food Irradiation: Why Aren’t We Using It?” J.D. Dessertation,. Havard Law School, Harvard, 2001.

[4] J. S. Smith and S. Pillai, "Irradiation and Food Safety," Food Safety, Vol. 58, No. 11, 2004, pp. 48-55.

[5] L. N. Christiansen, "Factors Influencing Botulinal Inhibition by Nitrite,” Food Technology, Vol. 10, 1980, pp. 237239.

[6] K. G. Duodu, A. Minnaar and J. R. N. Taylor, "Effect of Cooking and Irradiation on the Labile Vitamins and Antinutrient Content of a Traditional African Sorghum Porridge and Spinach Relish,” Food Chemistry, Vol. 66, No. 1, 1999, pp. 21-27. doi:10.1016/S0308-8146(98)00070-3

[7] Association of Official Analytical Chemists, "Official Methods of Analysis of the Association of Official Analytical Chemists,” Method 39.1.21., Washington DC, 1995.

[8] A. Anellis, E. Shattuck, D. B. Rowley, E. W. Ross, D. N. Whaley and V. R. Dowell, "Low-Temperature Irradiation of Beef and Methods for Evaluation of a Radappertization Process,” Applied Microbiology, Vol. 30, No. 5, 1975, pp. 811-820.

[9] "General Standard for Irradiated Foods Codex Standards 106-1983,” 2003.

http://www.codexalimentarius.net/download/standards/16 /CXS_106e.pdf

[10] W. B. Hugo and A. D. Russell, "Type of Antimicrobial Agents,” In: A. D. Russell, W. B. Hugo and G. A. J. Ayliffe, Eds., Principles and Practice of Disinfection, Preservation and Sterilization, Blackwell Scientific Publication, Oxford, 1982, p. 8.

[11] A. Anderson, U. Ronner and P. Granum, "What Problems Does the Food Industry Have with Spore-Forming Pathogens, Bacillus cereus and Clostridium perfrigens?” International Journal of Food Microbiology, Vol. 28, No. 2, 1995, pp. 145-155.

[12] F. M. Driessen, "Importance of Bacillus cereus in Fer- meted Milks and Processed Non-Fermented Dairy Foods,” Bulletin of the International Dairy Federation, Vol. 287, 1992, pp. 11-15.

[13] M. W. Peck, B. M. Lund, D. A. Fairbairn, A. S. Kaspersson and P. C. Underland, "Effect of Heat Treatment on Survival of and Growth from Spores of No-Proteolytic Clostridium botulinum at Refrigeration Temperatures," Applied and Environmental Microbiology, Vol. 61, No. 5, 1995, pp. 1780-1785.

[14] J. M. Jay, “Modern Food Microbiology,” Chapman \& Hall, New York, 1992.

[15] R. B. Tompkin, "Nitrate and Nitrite,” In: P. M. Davidson and A. L. Brasnen, Eds., Antimicrobials in Foods, Marcel Dekker, New York, 1998, pp. 205-256.

[16] T. M. Abo Bakr, S. M. El-Iraqui and M. H. Huissen, "Nitrate and Nitrite Contents of Some Fresh and Processed Egyptian Vegetables,” Food Chemistry, Vol. 19, No. 4, 1986, pp. 265-275. doi:10.1016/0308-8146(86)90050-6

[17] F. Yang, E. Troncy, M. Francoeur, B. Vinet, P. Vinay, G. Czaika and G. Blaise, "Effects of Reducing Reagents and Temperature on Conversion of Nitrite and Nitrate to Nitric Oxide and Detection of NO by Chemiluminescence," Clinical Chemistry, Vol. 43, No. 4, 1997, pp. 657-662.

[18] N. L. Mondy, S. K. Koushik and L. B. Munshi, "Irradiation and Packaging Affect the Nitrate-Nitrogen Concentrations of Potatoes," Journal of Food Science, Vol. 57, No. 6, 1992, pp. 1357-1358. doi:10.1111/j.1365-2621.1992.tb06856.x

[19] B. R. Thakur and R. K. Singh, "Food Irradiation-Chemistry and Applications," Food Review International, Vol. 10, No. 4, 1994, pp. 437-473. doi:10.1080/87559129409541012

[20] N. Nygaard and K. M. Lie, "Inactivation of Clostridium Sporogenes Spores in Fish By-Products by a New Processing Method,” 2011. http://www.nofima.no/filearchive/Rapport\%2010-2011.pdf

[21] H. Pivinick, M. A. Johnston, C. Thacker and R. Loynes, "Effect of Nitrite on Destruction and Germination of Clostridium botulinum and Putrefactive Anaerobes 3679 and $3679 \mathrm{~h}$ in Meat and in Buffer," Canadian Institute of Food Technology Journal, Vol. 3, No. 3, 1970, p. 103.

[22] J. F. Diehl, "Safety of Irradiated Foods,” Marcel Dekker, Inc., New York, 1990. 